\title{
Assessment of a new bio-organic remediation as a bio- fungicide in fusarium-infested soils of watermelon monoculture areas from China
}

Huai-a Liu ${ }^{1}$, Jesús Rodrigo Comino ${ }^{3,4^{*}}$, Hong-sheng Wu², Guang-yao Yang ${ }^{2}$, Xiao-ling Ma² Xiao-jun Wang ${ }^{4,5}$, Kai-kai Chen ${ }^{2}$, Ya-dong Liu ${ }^{6}$, Eric C. Brevik ${ }^{7}$

${ }^{1}$ Laboratary of Plant Protection, Lixiahe Regional Research Institute of Agricultural Science, Jiangsu Academy of Agricultural Sciences, Yangzhou 225008, Jiangsu, China. ${ }^{2}$ Department of Agricultural Resource and Environment, Nanjing University of Information Science and Technology, Nanjing 210044, China. ${ }^{3}$ Instituto de Geomorfología y Suelos, Department of Geography, University of Málaga, Edificio Ada Byron, Ampliación del Campus de Teatinos, 29071, Málaga, Spain. ${ }^{4}$ Department of Physical Geography, Trier University, D-54286 Trier, Germany. ${ }^{5}$ Guyuan Branch of Ning xia Academy of Agriculture and Forestry, 756000, Guyuan, China. ${ }^{6} Y a n g z h o u$ Polytechnic Institute, Yangzhou 225127, China. ${ }^{7}$ Department of Natural Sciences, Dickinson State University, Dickinson, ND, USA.*Corresponding author: rodrigo-comino@uma.es,wuhsglobe@sina.com

\begin{abstract}
Sustainably managed soils can increase soil quality, biodiversity, and reduce soil erosion and nutrient losses. In several regions of China, long-term monocultures such as watermelon are leading to severe degradation of soil biological functions due to contamination by dominant and deleterious microbes, particularly Fusarium spp., resulting in decreased soil productivity and quality.

The main goal of this study was to assess a new bio-organic fertilizer in monoculture areas by testing the interactions between Fusarium oxysporum f. sp. niveum and microbial communities to inhibit it. The results showed that the tested organism significantly reduced Fusarium wilt in a watermelon monoculture plantation in China. The rate of wilt incidence following bio-fertilizer treatment was decreased by $70 \%$ at 63 days and the Fusarium counts in the watermelon rhizosphere declined too. Moreover, total abundance of bacteria increased, but total abundance of actinomycetes decreased.

The beneficial microbes increased and became dominant while deleterious microbes, particularly Fusarium spp., were inhibited. The main conclusions of this study were that: i) a controlled bio-organic fertilizer stimulated the growth of ecologically beneficial microbes and naturally existing autochthonous antagonistic microbes; and, ii) the beneficial population structure and soil functions recovered following the reconstruction of functional microbial communities. Our results will add more useful information to understand how long-term crop monocultures can lead to detrimental effects on the soil microbial communities that will, in turn, affect the growth of plants and normal soil functions.
\end{abstract}

Keywords: Fusarium oxysporum f. sp. niveum, bio-organic fertilizer, watermelon monoculture, biological soil contamination. 


\section{Introduction}

Soils play a major role in providing mineral nutrients, water and a substrate to plants, and soil properties affect the health of natural and agroecosystems as well as human health. Soil quality is threatened by increasing human populations and the fact that most cultivable land is intensively used (Khaledian et al., 2016). Therefore, we have to protect this resource and invest efforts into research about soil health (Zornoza et al., 2015). Modified soil physical parameters (porosity, near-saturated hydraulic conductivity, aggregate stability and soil structure) have resulted from uninterrupted agricultural production, but these management systems (planting grasses and trees, irrigation etc.) do not always affect crop yields (Costa et al., 2015).

In China, long-term monoculture has led to severe soil sickness and as a consequence, high concentrations of accumulated Fusarium oxysporum in watermelon producing soils (Wu et al., 2010). Soil bio-fertility and productivity decline when this pathogen accumulates in the soil profile. Fusarium oxysporum Schleicher: Fr. f.sp. niveum (E.F. Smith) W. C. Snyder \& H. N. Hans. is the most important soil-borne pathogen that decreases watermelon production worldwide ( $\mathrm{Wu}$ et al., 2009).

Fusarium-infested soil affects normal production functions by decreasing yield because the soil becomes unhealthy and is no longer suitable for cultivation (Utkhede, 2006). A non-chemical method for crop protection against phytopathogenic fungi can be biocontrol via antagonistic organisms (Singh et al., 1999; Jimtha et al., 2016). Since the last century, organic fertilizers have been recommended for controlling Fusarium wilt in infested soils (Fulton, 1927). It appears that blending many microbes could be more effective than using one strain for promoting plant growth (Ahemad and Kibret, 2014; Jimtha et al., 2016). Another applied solution is the use of composted organic wastes as soil amendments (Calleja-Cervantes et al., 2015). Organic fertilizers not only supply organic matter to the soil, they also help: (1) form soil aggregates (Yazdanpanah et al., 2016); (2) improve soil porosity, bulk density and water holding capacity (Burrell et al., 2016); (3) conserve and increase the microbial diversity (Dignam et al., 2016); (4) remediate heavy metal and polycyclic aromatic compounds in contaminated soils (Chen et al., 2015); and, (5) promote crop growth (Sirohi et al., 2015; Debiase et al., 2016). Microbes introduced with organic fertilizers may inhibit plant pathogens (Wu et al., 2015; Ling et al., 2016).

Over the last few decades, little attention has been paid to the microbial-based ecological remediation of Fusarium-infested soils in watermelon plantations by using bio-organic fertilizers containing antagonistic (e.g. Paenibacillus polymixa and/or Trichoderma harzianum) and organic amendments through the regulation of beneficial and deleterious autochthonous microbes (Marín-Benito et al., 2014). Therefore, the main goals of this work are to: (1) assess the effectiveness of a new organic fertilizer; and, (2) investigate the remediation and functional recovery mechanisms in Fusarium-infested soils amended with the new bioorganic fertilizer. The hypotheses of this work are related to: (1) bio-organic fertilizer as inhibitor of deleterious soil microbes; and, (2) bio-organic fertilizer as tool to rebalance the soil microbial ecology and to restore the production function of sick soils.

\section{Materials and Methods}

\subsection{Experimental design and conditions}

This research was conducted under laboratory conditions in a completely randomized block, which was designed with five replications with watermelon 
plants as described in Table 1 (Wu et al., 2009; Cao et al., 2011). For this research, Fusarium-infested samples from yellow sandy loam soils (Table 2), classified as Alfisols were collected. Samples were collected from the top ayers of soils in which watermelons were grown continuously during a natural cycle of five years in Shanghai (China), and healthy (Fusariumfree) soil from neighboring watermelon-cultivated soil was also collected (soil free of watermelon, E $\left.31^{\circ} 00 \mathrm{~N} 121^{\circ} 45\right)$.

Table 1. Treatments applied to the Fusarium-infested soils in this study. CK: untreated soil; CF: soil with chemical fertilizer; $0.1 \%$ OF: soil with $0.1 \%$ organic fertilizer; $0.5 \%$ OF: soil with $0.5 \%$ organic fertilizer; $0.1 \%$ BOF: soil with $0.1 \%$ organic fertilizer and antagonistic microbes; and, $0.5 \%$ BOF: soil with $0.5 \%$ organic fertilizer and antagonistic microbes.

\begin{tabular}{|c|c|c|}
\hline ID & Treatments & Observations \\
\hline $\mathrm{CK}$ & Untreated & - \\
\hline $\mathrm{CF}$ & $\begin{array}{l}\text { Applying chemical } \\
\text { fertilizer }\end{array}$ & $\begin{array}{l}\text { Containing equal amounts of } \mathrm{N}, \mathrm{P} \text {, and } \mathrm{K}+ \\
0.1 \% \text { organic fertilizer, which was blended } \\
\text { with: } \\
\quad \checkmark\left(\mathrm{NH}_{4}\right)_{2} \mathrm{SO}_{4}(18.0 \% \mathrm{~N}) \mathrm{Ca}\left(\mathrm{H}_{2} \mathrm{PO}_{4}\right)_{2} \\
\checkmark \checkmark \mathrm{H}_{2} \mathrm{O}\left(52.6 \% \mathrm{P}_{2} \mathrm{O}_{5}\right) \\
\checkmark \mathrm{K}_{2} \mathrm{SO}_{4}\left(60 \% \mathrm{~K}_{2} \mathrm{O}\right)\end{array}$ \\
\hline $0.1 \% \mathrm{OF}$ & $\begin{array}{l}\text { Applying } 0.1 \% \text { organic } \\
\text { fertilizer }\end{array}$ & \\
\hline $0.5 \% \mathrm{OF}$ & $\begin{array}{l}\text { Applying } 0.5 \% \text { organic } \\
\text { fertilizer }\end{array}$ & $\begin{array}{l}\text { Treatment based on the weights of wet soil- } \\
\text { filled pots, with the same metric used hereafter }\end{array}$ \\
\hline $0.1 \%$ & $\begin{array}{l}\text { Applying } 0.1 \% \text { organic } \\
\text { fertilizer and }\end{array}$ & \\
\hline $\mathrm{BOF}$ & $\begin{array}{l}\text { fertllizer and } \\
\text { antagonistic microbes }\end{array}$ & $\begin{array}{l}\text { Treatment conducted with organic matter with } \\
\text { antagonistic microorganisms }\end{array}$ \\
\hline $\begin{array}{l}0.5 \% \\
\mathrm{BOF}\end{array}$ & $\begin{array}{l}\text { Applying } 0.5 \% \text { organic } \\
\text { fertilizer and } \\
\text { antagonistic microbes }\end{array}$ & \\
\hline
\end{tabular}

*Bio-organic fertilizer (BOF) means suitable living microbes and their spores were mixed with organic fertilizer when pig or chicken manures were fermented.

Table 2. Chemical properties of the tested soils.

\begin{tabular}{ccccccc}
\hline Soil Type (units) & $\begin{array}{c}\text { Organic } \\
\text { matter } \\
\left(\mathrm{g} \mathrm{kg}^{-1}\right)\end{array}$ & $\begin{array}{c}\text { Total N } \\
\left(\mathrm{g} \mathrm{kg}^{-1}\right)\end{array}$ & $\begin{array}{c}\mathrm{N} \\
\left(\mathrm{g} \mathrm{kg}^{-1}\right)\end{array}$ & $\begin{array}{c}\mathrm{P} \\
\left(\mathrm{mg} \mathrm{kg}^{-1}\right)\end{array}$ & $\begin{array}{c}\mathrm{K} \\
\left(\mathrm{mg} \mathrm{kg}^{-1}\right)\end{array}$ & $\mathrm{pH}_{\mathrm{H}_{2} \mathrm{O}}$ \\
\hline Fusarium-infested soil & 41.73 & 1.21 & 25.01 & 6.2 & 392.68 & 8.02 \\
Non-planted soil & 24.50 & 1.15 & 20.59 & 4.69 & 262.21 & 6.08 \\
\hline
\end{tabular}


Soil samples were air-dried and passed through a $2 \mathrm{~mm}$-mesh screen. All fertilizers and antagonistic microbes were mixed thoroughly with Fursariuminfested soil before transplanting to ensure homogeneity. Chemical fertilizer was dissolved in $100 \mathrm{~mL}$ distilled water to mix and then blended with half of 5 $\mathrm{kg}$ potted soil and subsequently mixed with the other half of the $5 \mathrm{~kg}$ of potted soil. The $100 \mathrm{~mL}$ antagonistic microbes (Trichoderma guizhouense GenBank accession number: GQ337429 and Panaebacillus polymixa GenBank accession number: GU377210.1) suspension was added to the one third of the $5 \mathrm{~kg}$ of potted soil to blended and then the blended soil was mixed with the left soil thoroughly. Watermelon seeds (Citrullus lanatus Thunb. Matsum. \& Nakai, Chinese commercial name Zaojia 84-24) were surface-disinfected by applying $2 \%$ sodium hypochlorite solution for $15 \mathrm{~min}$ and then dipped in $50{ }^{\circ} \mathrm{C}$ sterile water for $10 \mathrm{~min}$ to promote germination. The disinfected seeds were placed on moist filter paper in a Petri dish at $30{ }^{\circ} \mathrm{C}$ until germination. Ten germinated seeds were sown into each pot.

Two weeks later, 8 seedlings were selected for the experiment. The soil was sprayed with $150 \mathrm{ml}$ of distilled water per pot every 2 days during the first 3 weeks and then with $300 \mathrm{ml}$ thereafter. All the pots were distributed randomly throughout a greenhouse with natural light conditions. The temperatures were kept at a maximum of $35^{\circ} \mathrm{C}$ during the day and at $21{ }^{\circ} \mathrm{C}$ at night. The pathogen Fusarium oxysporum f. sp. niveum was isolated and identified from Fusarium-infested soil and watermelon seedlings before the experimentation phase. The Fusarium wilt incidence for watermelon cultivated soils and its symptoms were observed and identified 63 days from the treatment. Wilting leaves and the discoloration of vascular tissue in the watermelon root transection were used as elementary diagnostic symptoms for Fusarium wilt in watermelon (Wu et al., 2009, 2010).

\subsection{Fertilizers and antagonistic microbes, and soil analysis}

The applied bio-organic fertilizer consisted of organic fertilizer fermented from soybean cakes, and characterized by the properties described in Table 2 , and it contained antagonistic microbes, namely $3 \times 10^{9}$ viable Paenibacillus polymyxa spores per gram of organic fertilizer and $5 \times 10^{6}$ viable conidia of Trichoderma guizhouense per gram of organic fertilizer (Wu et al., 2009).

Komada selective medium was used for the isolation, identification and enumeration of Fusarium spp. (Komada, 1975). The enumeration of culturable soil microbes was performed as described by (Wu et al., 2009, 2010). Standard dilution plate methods were used to count the strain, in which the suspension concentrations were serially diluted from $10^{-6}$ to $10^{-8}$ for bacteria, $10^{-4}$ to $10^{-6}$ for actinomycetes, and $10^{-2}$ to $10^{-4}$ for other fungi and Fusarium spp. propagules. The rhizosphere soil was sampled 63 days from the treatmentand the wilt incidence was recorded using a watermelon plant disease index. The effects of the treatments on culturable microorganisms in the watermelon rhizosphere were tested at the same time. Two plants were randomly selected from each pot to investigate the rhizosphere microflora. The roots were cut and weighed after removing the excess soil by shaking the plant gently. They were subsequently: i) washed by vortexing them in sterile distilled water; ii) blotted dry; and, iii) weighed again. After determining the amounts of suspended soil, the rhizosphere suspension was diluted in a series from 10 to $10^{-8}$. A $0.1 \mathrm{ml}$ suspension was then plated on $2 \%$ malt agar (18 $\mathrm{g}$ of agar, $20 \mathrm{~g}$ of malt extract, and $1000 \mathrm{ml}$ of distilled water) that was acidified to a $\mathrm{pH}$ of 5.5 , and chloramphenicol (150 $\left.\mathrm{mg} \mathrm{L}^{-1}\right)$ was added to suppress bacteria. The plates were incubated at $28^{\circ} \mathrm{C}$, and most isolates were obtained five days later, but the plates 
were continuously examined over 3-4 weeks to isolate the slow-growing microorganisms.

The morphological identification of microbial isolates was conducted according to classical macro- and microscopic criteria based on cultural features (Wu et al., 2009, 2010, 2015). Bacterial physio-chemical reactions were also observed (Gordon et al., 1973; Speller, 1978). Actinomycetes were identified from classical macro-and microscopic criteria and physiochemical reactions (Shirling and Gottlieb, 1966; Hasegawa et al., 1983). The morphological identification of fungal isolates was conducted using classical

$$
\begin{aligned}
& D_{M g}=(S-1) / \ln N \\
& H^{\prime}=-S U M p_{i}\left(\ln p_{i}\right)
\end{aligned}
$$

micro- and macroscopic criteria, including cultural features (Webley, 1973). Fusarium spp. was identified using supplementary literature (Booth, 1971).

The soil microbial species abundance, richness, and diversity indices were calculated to show the effect of biocontrol inoculants on resident soil populations (Natsch et al., 1997). To compare the treatment effects, diverse indices (species richness and species abundance indices) were used. Margalef's diversity measure (Equation 1) and Shannon's index (Equation 2) were applied as species richness indices (Girlanda et al., 2001).

\section{Equation 1}

Equation 2

In the Margalef's index, $\mathrm{S}$ is the number of taxa and $\mathrm{N}$ the total number of individuals. In Shannon's index, pi is the proportion of individuals in the ith species.

To measure the species abundance indices, Simpson's index (Equation 3) and Berger-Parker's index (Equation 4) were applied.

$$
\begin{gathered}
D=\operatorname{SUM}\left[n_{i}\left(n_{i}-1\right] /[N(N-1)]\right. \\
d=N_{\max } / N
\end{gathered}
$$

In the Simpson's index, $\mathrm{N}$ is the total number of individuals and ni stands for the total number of organisms of a particular specie. Berger-Parker's index was also used to indicate the proportional importance of the most abundant species from the

\section{Equation 3}

Equation 4

formula, where $\mathrm{N}_{\max }$ is the number of individuals in the most abundant species (Girlanda et al., 2001). An analysis of the dominant soil microbes was performed by standard dilution plate method (Wu et al., 2009, 2015). 


\subsection{Statistical analysis and data process}

The values for the watermelon plant wilt percentage and microbe counts (CFU) were expressed as means \pm standard deviation. A one-way analysis of variance (ANOVA) of the rate of Fusarium wilt in watermelon and the diversity indices were calculated with SPSS 23 (IBM, USA). Least significant difference tests were used for post-hoc comparisons, and the significance levels were set at $\mathrm{P}<0.05$.

\section{Results}

\subsection{Effect of bio-organic fertilizer on the Fusarium} wilt of watermelon plants

Bio-organic fertilizer (BOF) significantly inhibited Fusarium wilt in watermelon plants. The incidence rate of wilt for the $\mathrm{CK}$ at 63 days from the treatment was $70 \%$. The rate of wilt for treatments $\mathrm{CF}, 0.1 \%$ OF, $0.5 \%$ OF, $0.1 \%$ BOF and $0.5 \%$ BOF decreased to $61.3 \%, 40.3 \%, 31.7 \%, 30.3 \%$, and $20.7 \%$ in comparison with the control treatment, respectively (Figure 1). The rates of wilt for all OF and BOF treatments were lower than in the $\mathrm{CF}$.

\subsection{Microflora analysis and evaluation of microbial} abundance into the soil and rhizosphere

Margalef's species richness, Shannon's, Simpson's and Berger-Parker's indices were used independent of the cultivation history (Table 3 ): before trial and 63 days from the treatment.

The planting of watermelons and the application of fertilizers affected the quantities of culturable microorganisms in the rhizosphere and bulk soil, particularly for $\mathrm{OF}$ and $\mathrm{BOF}$ treatments. Applications of $\mathrm{CF}, \mathrm{OF}$ and $\mathrm{BOF}$ affected the quantities and dynamic equilibrium of culturable microorganisms in the rhizosphere (Table 3). Compared with the healthy soil (Table 4) the CFU or microbial abundance of total culturable bacteria in Fusarium-infested soil was lower, whereas the CFU of culturableactinomycetes, other fungi and Fusarium spp. was higher. The total bacterial count in Fusarium-infested soil declined by $22.8 \%$ relative to its value in healthy soil; however, the CFU of total actinomycetes increased by $117.4 \%$, with total fungi elevated by $473.5 \%$ and total Fusarium spp. increased by $157.7 \%$ in comparison with that of healthy soil, respectively (Figure 2).

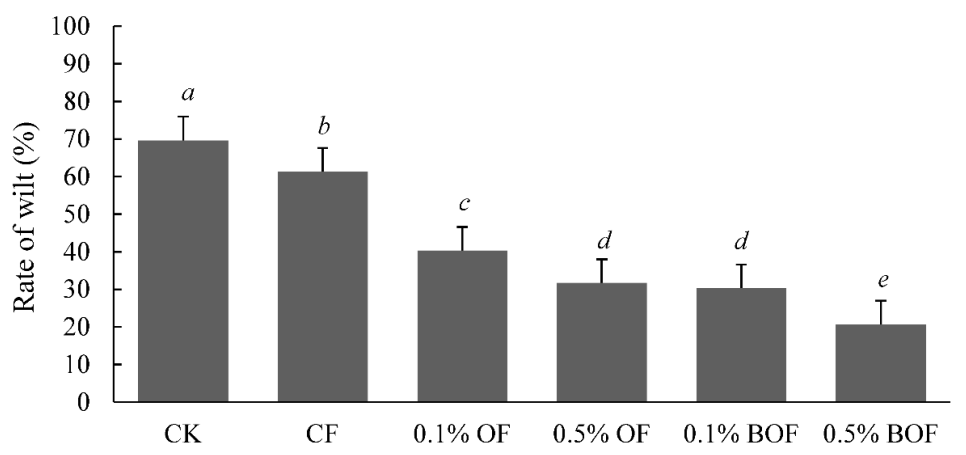

Figure 1. Rate of watermelon plant wilting at 63 days from the treatment. CK: untreated soil; CF: soil with chemical fertilizer; $0.1 \%$ OF: soil with $0.1 \%$ organic fertilizer; $0.5 \%$ OF: soil with $0.5 \%$ organic fertilizer; $0.1 \%$ BOF: soil with $0.1 \%$ organic fertilizer and antagonistic microbes; and, $0.5 \%$ BOF: soil with $0.5 \%$ organic fertilizer and antagonistic microbes. 
Table 3. Effects of bio-organic fertilizer on microbial species diversity in treated soil. The same letters were not significantly different in post-hoc tests $(\mathrm{P}<0.05)$. $\mathrm{CK}$ : untreated soil; $\mathrm{CF}$ : soil with chemical fertilizer; $0.1 \% \mathrm{OF}$ : soil with $0.1 \%$ organic fertilizer; $0.5 \%$ OF: soil with $0.5 \%$ organic fertilizer; $0.1 \%$ BOF: soil with $0.1 \%$ organic fertilizer and antagonistic microbes; and, $0.5 \%$ BOF: soil with $0.5 \%$ organic fertilizer and antagonistic microbes.

\begin{tabular}{llllll}
\hline & Soil Type & Margalef & Shannon & Simpson & Berger-Parker \\
\hline $\begin{array}{l}\text { Before } \\
\text { trial }\end{array}$ & Non-cultivated soil & $2.32 \pm 0.22 \mathrm{a}$ & $0.01 \pm 0.00 \mathrm{a}$ & $50.91 \pm 4.77 \mathrm{a}$ & $1.00 \pm 0.1 \mathrm{a}$ \\
& Infested soil & $2.45 \pm 0.29 \mathrm{a}$ & $0.13 \pm 0.02 \mathrm{~b}$ & $48.99 \pm 5.85 \mathrm{a}$ & $1.00 \pm 0.12 \mathrm{a}$ \\
& $\begin{array}{l}\text { Non-watermelon-cultivated } \\
\text { soil }\end{array}$ & $2.71 \pm 0.84 \mathrm{~b}$ & $0.11 \pm 0.03 \mathrm{~b}$ & $49.79 \pm 15.43 \mathrm{a}$ & $1.00 \pm 0.31 \mathrm{a}$ \\
& Infested soil & $2.78 \pm 0.13 \mathrm{~b}$ & $0.55 \pm 0.02 \mathrm{~d}$ & $50.91 \pm 2.29 \mathrm{a}$ & $0.99 \pm 0.04 \mathrm{a}$ \\
63days & CF & $2.74 \pm 0.14 \mathrm{~b}$ & $0.35 \pm 0.02 \mathrm{c}$ & $51.30 \pm 2.61 \mathrm{bc}$ & $0.99 \pm 0.05 \mathrm{a}$ \\
from the & $0.1 \%$ OF & $2.65 \pm 1.20 \mathrm{~b}$ & $0.13 \pm 0.06 \mathrm{~b}$ & $51.73 \pm 23.35 \mathrm{bc}$ & $1.00 \pm 0.45 \mathrm{a}$ \\
treatment & $0.5 \%$ OF & $2.60 \pm 0.50 \mathrm{~b}$ & $0.10 \pm 0.02 \mathrm{~b}$ & $51.80 \pm 9.90 \mathrm{bc}$ & $1.00 \pm 0.20 \mathrm{a}$ \\
& $0.1 \%$ BOF & $2.61 \pm 0.52 \mathrm{~b}$ & $0.10 \pm 0.02 \mathrm{~b}$ & $51.80 \pm 10.29 \mathrm{bc}$ & $1.00 \pm 0.20 \mathrm{a}$ \\
& $0.5 \%$ BOF & $2.54 \pm 0.52 \mathrm{~b}$ & $0.06 \pm 0.01 \mathrm{a}$ & $51.87 \pm 10.69 \mathrm{bc}$ & $1.00 \pm 0.21 \mathrm{a}$ \\
\hline
\end{tabular}

*Means with the same letters were not significantly different in post-hoc tests $(\mathrm{P}<0.05)$.

Table 4. CFU (abundance) of total microorganisms and count of dominant populations of microorganisms in the soil before the trial (means $\pm \mathrm{SE}$ ).

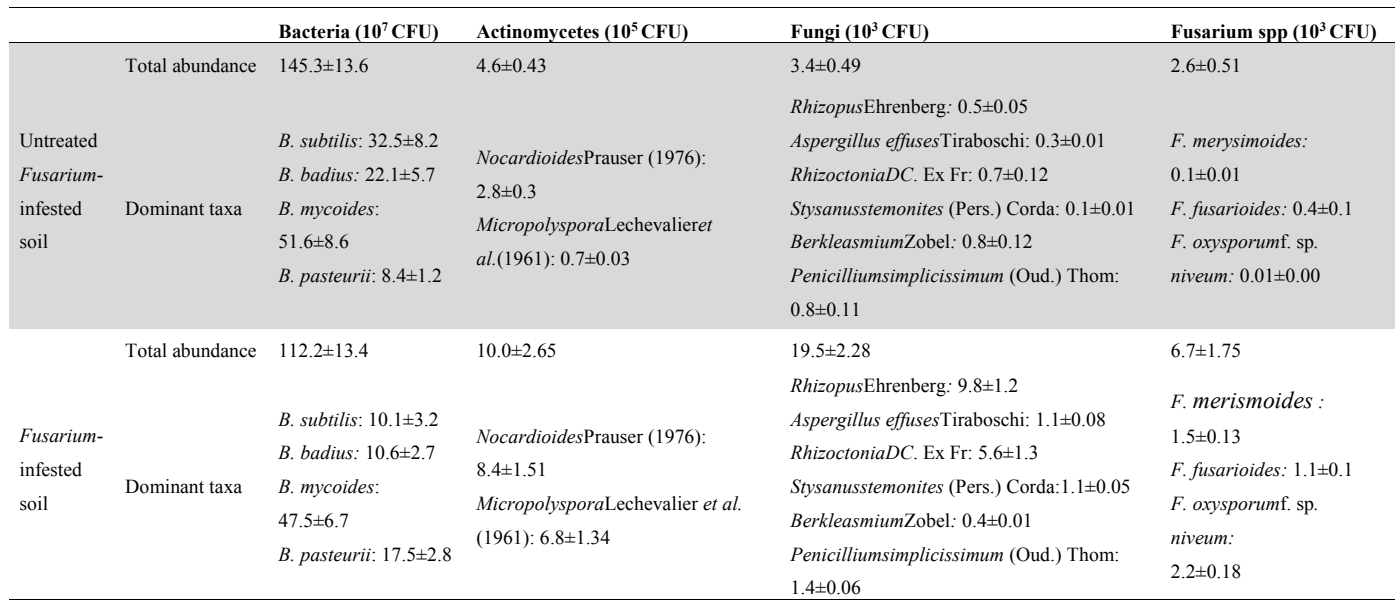




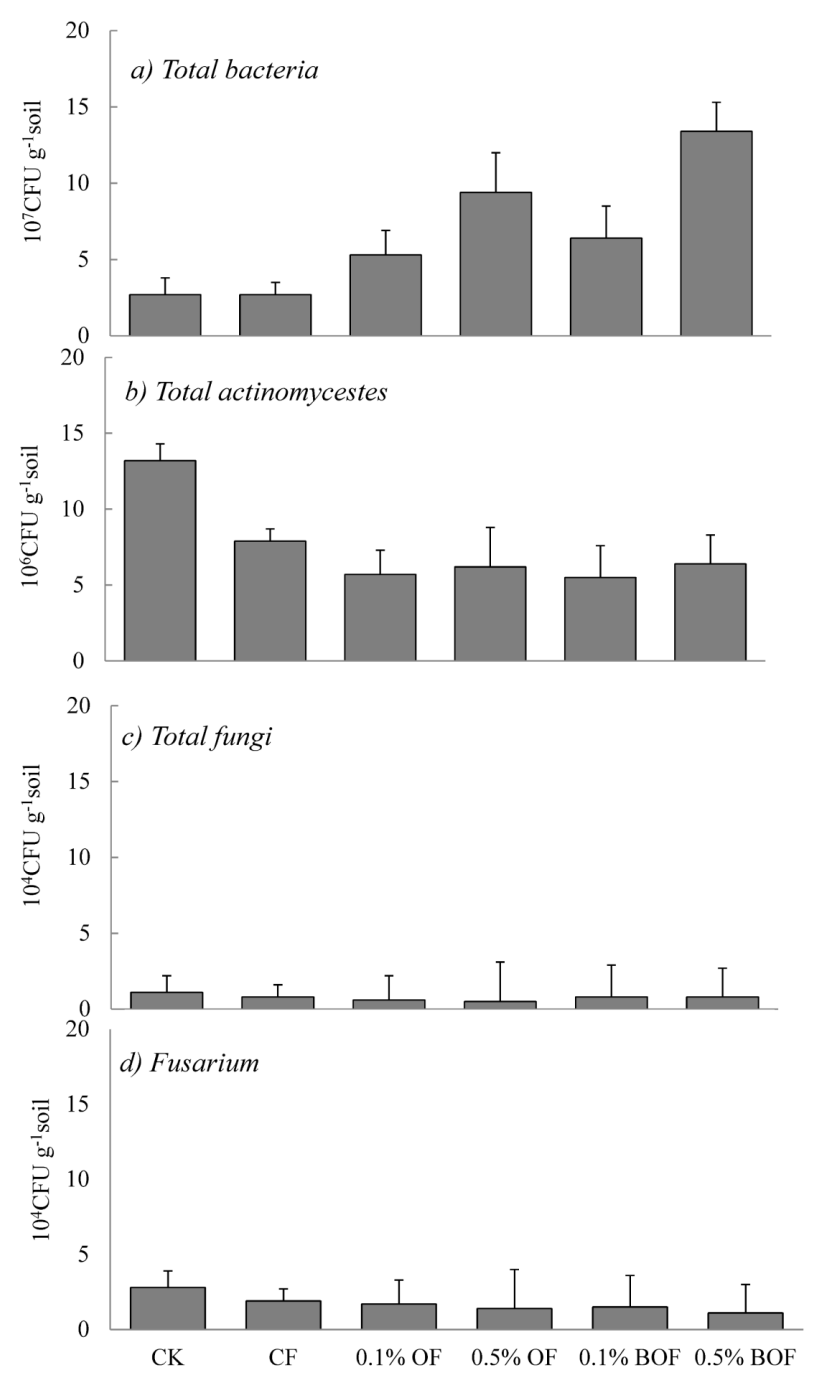

Figure 2. CFU (abundance) of total microorganisms in the watermelon rhizosphere 63 days from the treatment. CK: untreated soil; CF: soil with chemical fertilizer; $0.1 \%$ OF: soil with $0.1 \%$ organic fertilizer; $0.5 \%$ OF: soil with $0.5 \%$ organic fertilizer; $0.1 \%$ BOF: soil with $0.1 \%$ organic fertilizer and antagonistic microbes; and, $0.5 \%$ BOF: soil with $0.5 \%$ organic fertilizer and antagonistic microbes. 
The count of the dominant bacterial populations decreased from healthy soil to Fusarium-infested soil. The CFU values of $B$. subtilis, $B$. badius, and B. mycoides decreased by $68.9 \%, 52 \%$, and $7.9 \%$, respectively. However, the $B$. pasteurii value increased by $108.3 \%$.

The CFU of the dominant actinomycetes populations increased from healthy soil to Fusarium-infested soil. Some of these actinomycetes, namely Nocardioides (Prauser, 1976) and Micropolyspora Lechevalier (1961), increased by $200 \%$ and approximately $871.4 \%$, respectively.

An increase in the CFU of the dominant fungal populations in Fusarium-infested soil was found. In comparison with the healthy soil, the CFU of Rhizopus Ehrenberg, Aspergillus effuses Tirabschi, Rhizoctonia DC. Ex Fr., Stysanusstemonites (Pers.) Corda, and Penicillium simplicissimum (Oud.) Thom. increased by $1860 \%, 266.7 \%, 700 \%, 1000 \%$, and $75 \%$, respectively. However, Berkleasmium was reduced by $50 \%$. The dominant Fusarium spp. population was $F$. $f u$ sarioides in CK soil. An additional two Fusarium spp., namely $F$. fusarioides and $F$. oxysporum f. sp. niveum, were also common Fusarium populations in Fusarium-infested soil, particularly FON (Fusarium oxysporum f. sp. niveum).
3.3. Microflora analysis: evaluation of abundance and dominant populations after the treatment

At 63 days from the treatment, the CFU of total culturable bacteria for the $\mathrm{OF}$ and $\mathrm{BOF}$ treatments were higher than that of the CK (Figure 2). The highest was for the $0.5 \%$ BOF treatment with $13.410^{7} \mathrm{CFU} \mathrm{g}^{-1}$ soil and the lowest $\mathrm{CK}$ (2.7 $10^{7} \mathrm{CFU} \mathrm{g}^{-1}$ soil). The highest number of culturable actinomycetes was in the $\mathrm{CK}$ treatment $\left(13.210^{6} \mathrm{CFU} \mathrm{g}^{-1}\right.$ soil) and, the lowest were $0.1 \%$ OF and $0.1 \%$ BOF with $<610^{6} \mathrm{CFU} \mathrm{g}^{-1}$ soil. The culturable fungi count was reduced for $\mathrm{CF}, 0.1 \% \mathrm{OF}$ and $0.5 \%$ OF compared to $\mathrm{CK}$. The fungal counts for $0.1 \%$ BOF and $0.5 \%$ BOF increased. The CFU of the total Fusarium spp. for CF was slightly less (1.9 $10^{4}$ CFU g ${ }^{-1}$ soil) than that of $\mathrm{CK}\left(1.910^{4} \mathrm{CFU} \mathrm{g}^{-1}\right.$ soil $)$, but the $\mathrm{OF}$ and $\mathrm{BOF}$ treatment values all declined sharply, particularly for $0.1 \% \mathrm{BOF}$ and $0.5 \% \mathrm{BOF}$, showing 1.5 $10^{4} \mathrm{CFU} \mathrm{g}^{-1}$ soil and $1.110^{4} \mathrm{CFU} \mathrm{g}^{-1}$ soil, respectively. Information related to the CFU of dominant microbial populations in the watermelon rhizosphere at 63 days from the treatment can be noted in Table 5. The CFU of $B$. subtilis was increased in all treatments, but not in CF. The CFU of B. badius also declined, with the exception of OF and BOF (with 400-700 times the value of $\mathrm{CK})$. 
Table 5. CFU (abundance) of dominant microbial populations in the watermelon rhizosphere at 63 days from the treatment.

\begin{tabular}{|c|c|c|c|c|}
\hline & Bacteria $\left(10^{7} \mathrm{CFU}\right)$ & Actinomycetes $\left(10^{5} \mathrm{CFU}\right)$ & Fungi $\left(10^{3} \mathrm{CFU}\right)$ & Fusarium spp. $\left(10^{3} \mathrm{CFU}\right)$ \\
\hline CK & $\begin{array}{l}\text { B. subtilis: } 8 \pm 2.6 \\
\text { B. badius: } 4.5 \pm 0.3 \\
\text { B. mycoides: } 17.3 \pm 2.3 \\
\text { B. pasteurii }: 4 \pm 1.1\end{array}$ & $\begin{array}{l}\text { NocardioidesPrauser (1976):6.2 } \pm 1.2 \\
\text { MicropolysporaLechevalier et al. (1961): } 6.1 \pm 2.1\end{array}$ & $\begin{array}{l}\text { Re: } 0.2 \pm 0.03 \\
\text { Ae: } 0.0 \pm 0.0 \\
\text { Rh: } 0.5 \pm 0.06 \\
\text { Ss: } 0.0 \pm 0.0 \\
\text { Bz: } 0.0 \pm 0.0 \\
\text { Ps: } 0.3 \pm 0.02\end{array}$ & $\begin{array}{l}\text { F. merismoides: } 0.7 \pm 0.15 \\
\text { F. fusarioides: } 2.3 \pm 0.7 \\
\text { F. oxysporumf. sp. niveum: } 2.9 \pm 0.07\end{array}$ \\
\hline $\mathrm{CF}$ & $\begin{array}{l}\text { B. subtilis: } 33.7 \pm 8.1 \\
\text { B. badius: } 3.2 \pm 1.1 \\
\text { B. mycoides: } 20.9 \pm 1.5 \\
\text { B. pasteurii:: } 11.5 \pm 3.1\end{array}$ & $\begin{array}{l}\text { NocardioidesPrauser (1976):05. } \pm 0.07 \\
\text { MicropolysporaLechevalier et al. (1961): } 5.2 \pm 2.1\end{array}$ & $\begin{array}{l}R e: 0.2 \pm 0.02 \\
\text { Ae: } 0.2 \pm 0.02 \\
R h: 0.6 \pm 0.1 \\
S s 0.0 \pm 0.0: \\
B z: 0.0 \pm 0.0 \\
P s: 0.7 \pm 0.15\end{array}$ & $\begin{array}{l}\text { F. erismoides: } 2.5 \pm 0.7 \\
\text { F. fusarioides: } 3.1 \pm 0.6 \\
\text { F. oxysporumf. sp. niveum: } 3.1 \pm 0.6\end{array}$ \\
\hline $0.1 \% \mathrm{OF}$ & $\begin{array}{l}\text { B. subtilis: } 25.9 \pm 3.9 \\
\text { B. badius: } 13.8 \pm 3.2 \\
\text { B. mycoides: } 26.5 \pm 4.1 \\
\text { B. pasteurii:: } 15.0 \pm 2.0\end{array}$ & 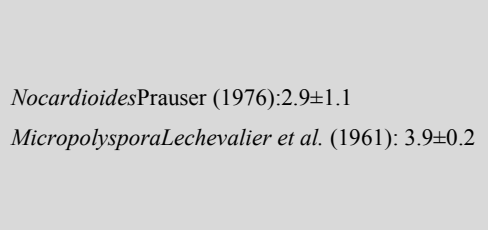 & $\begin{array}{l}\text { Re: } 0.6 \pm 0.1 \\
\text { Ae: } 0.1 \pm 0.01 \\
\text { Rh: } 0.7 \pm 0.15 \\
\text { Ss: } 0.3 \pm 0.02 \\
\text { Bz:0.2 } 2 \pm 0.02 \\
\text { Ps: } 2.8 \pm 0.5\end{array}$ & $\begin{array}{l}\text { F. erismoides: } 2.6 \pm 1.1 \\
\text { F. fusarioides: } 1.9 \pm 0.3 \\
\text { F. oxysporumf. sp. niveum: } 1.5 \pm 0.2\end{array}$ \\
\hline $0.5 \% \mathrm{OF}$ & $\begin{array}{l}\text { B. subtilis: } 26.4 \pm 5.1 \\
\text { B. badius: } 16.7 \pm 3.8 \\
\text { B. mycoides: } 28 \pm 5.1 \\
\text { B. pasteurii }: 38.6 \pm 9.7\end{array}$ & $\begin{array}{l}\text { NocardioidesPrauser (1976): } 0.7 \pm 0.06 \\
\text { MicropolysporaLechevalier et al. (1961): } 0.5 \pm 0.1\end{array}$ & $\begin{array}{l}\text { Re: } 2.1 \pm 0.7 \\
\text { Ae: } 0.0 \pm 0.0 \\
R h: 0.7 \pm 0.2 \\
\text { Ss:0.5 } \pm 0.1 \\
B z: 0.4 \pm 0.05 \\
\text { Ps: } 3.0 \pm 0.8\end{array}$ & $\begin{array}{l}\text { F. erismoides: } 0.8 \pm 0.1 \\
\text { F. fusarioides: } 0.7 \pm 0.1 \\
\text { F. oxysporumf. sp. niveum: } 1.0 \pm 0.15\end{array}$ \\
\hline $0.1 \% \mathrm{BOF}$ & $\begin{array}{l}\text { B. subtilis: } 29.6 \pm 6.9 \\
\text { B. badius: } 18.8 \pm 5.4 \\
\text { B. mycoides: } 30.4 \pm 6.8 \\
\text { B. pasteurii: }: 33.5 \pm 4.1\end{array}$ & $\begin{array}{l}\text { NocardioidesPrauser (1976): } 2.3 \pm .07 \\
\text { MicropolysporaLechevalier et al. (1961): } 0.7 \pm 0.2\end{array}$ & $\begin{array}{l}\text { Re: } 2.8 \pm 1.2 \\
\text { Ae: } 0.0 \pm 0.0 \\
R h: 3.7 \pm 1.1 \\
\text { Ss: } 0.1 \pm 0.01 \\
\text { Bz: } 0.8 \pm 0.15 \\
\text { Ps: } 3.9 \pm 0.4\end{array}$ & $\begin{array}{l}\text { F. erismoides: } 0.4 \pm 0.1 \\
\text { F. fusarioides: } 0.7 \pm 0.15 \\
\text { F. oxysporumf. sp. niveum: } 0.9 \pm 0.2\end{array}$ \\
\hline $0.5 \% \mathrm{BOF}$ & $\begin{array}{l}\text { B. subtilis: } 33.8 \pm 4.2 \\
\text { B. badius: } 22.1 \pm 2.4 \\
\text { B. mycoides: } 36.4 \pm 9.1 \\
\text { B. pasteurii : }: 38.7 \pm 11.1\end{array}$ & $\begin{array}{l}\text { NocardioidesPrauser (1976): } 0.2 \pm 0.02 \\
\text { MicropolysporaLechevalier et al. (1961): } 0.5 \pm 0.1\end{array}$ & $\begin{array}{l}\operatorname{Re}: 4.8 \pm 1.5 \\
\text { Ae: } 0.0 \pm 0.0 \\
R h: 3.6 \pm 1.2 \\
S s 0.6 \pm 0.13 \\
B z: 0.7 \pm 0.12 \\
P s: 4.1 \pm 0.4\end{array}$ & $\begin{array}{l}\text { F. erismoides: } 0.6 \pm 0.14 \\
\text { F. fusarioides: } 0.2 \pm 0.03 \\
\text { F. oxysporumf. sp. niveum: } 0.6 \pm 0.01\end{array}$ \\
\hline
\end{tabular}

*The values are means $\pm \mathrm{SD}, \mathrm{n}=3$.CK, Untreated Fusarium-infested soil; CF, Fusarium-infested soil treated with chemical fertilizer; $0.1 \%$ OF, Fusarium-infested soil treated with $0.1 \%$ organic fertilizer; $0.5 \%$ OF, Fusarium-infested soil treated with $0.5 \%$ organic fertilizer; $0.1 \%$ BOF, Fusarium-infested soil treated with $0.1 \%$ organic fertilizer containing antagonistic microbes; and $0.5 \%$ BOF, Fusarium-infested soil treated with $0.5 \%$ organic fertilizer containing antagonistic microbes. **Re: Rhizopus Ehrenberg; Ae: Aspergillus effuses Tiraboschi; Rh: Rhizoctonia DC. Ex Fr; Ss: Stysanus stemonites (Pers.) Corda; Bz: Berkleasmium Zobel; and Ps: Penicillium simplicissimum (Oud.) Thom. 
The CFU of B. mycoides declined when watermelon was planted, but increased for the BOF treatment. The CFU of B. pasteurii with $0.5 \%$ BOF was higher than in CK.

Nocardioides, an actinomycete, was decreased relative to that of CK for OF and BOF. Micropolyspora was not the dominant population in healthy soil, but it dominated after watermelon planting. For the $\mathrm{OF}$ and BOF treatments, the CFU decreased to only approximately $1 / 4$ of that of the $\mathrm{CK}$.

Rhizopus Ehrenberg was nearly unchanged for all of the treatments. Aspergillus effuses Tiraboschi was suppressed by $\mathrm{CF}$ and $\mathrm{OF}$ and stimulated by BOF. Rhizoctonia DC. Ex Fr. decreased in a rate-dependent manner, which was approximately 50\% lower than that of CK. In addition, Stysanus stemonites (Pers.) Corda increased with increased fertilizer application rate, particularly for the BOF, which was approximately $50 \%$ higher than that of CK. After watermelon planting, Berkleasmium Zobel decreased with fertilizer treatment. Penicillium simplicissimum (Oud.) Thom. changed little in CF and OF, but it decreased in BOF, which declined by approximately $45.5 \%$ and $70.0 \%$ for the $0.1 \% \mathrm{BOF}$ and $0.5 \% \mathrm{BOF}$ treatments, respectively.

Finally, results of dominant Fusarium spp. populations in the watermelon rhizosphere 63 days from the treatment can be observed in Figure 3. F. merismoides was also inhibited by $\mathrm{OF}$ and $\mathrm{BOF}$, particularly $0.5 \% \mathrm{BOF}$, which decreased the fungus by approximately $88.1 \%$. Additionally, the CFU of $F$. fusariodes decreased with increasing application rates of BOF and $\mathrm{OF}$, which reduced the fungus by approximately $50.0 \%$. Finally, the FON was decreased by $75.0 \%$ $87.5 \%$ in $0.1 \%$ OF and $0.5 \%$ BOF treatments in comparison with that of $\mathrm{CK}$. 

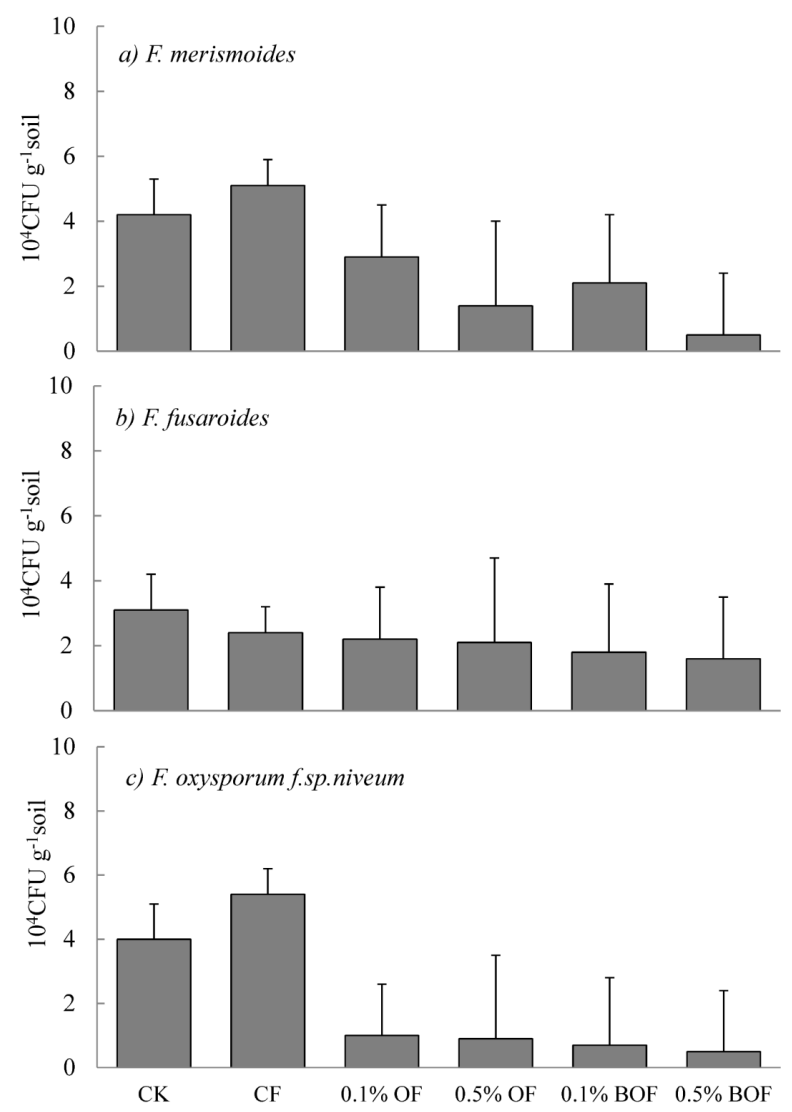

Figure 3. Dominant Fusarium spp. populations in the watermelon rhizosphere 63 days from the treatment. CK: untreated soil; $\mathrm{CF}$ : soil with chemical fertilizer; $0.1 \%$ OF: soil with $0.1 \%$ organic fertilizer; $0.5 \%$ OF: soil with $0.5 \%$ organic fertilizer; $0.1 \%$ BOF: soil with $0.1 \%$ organic fertilizer and antagonistic microbes; and, $0.5 \%$ BOF: soil with $0.5 \%$ organic fertilizer and antagonistic microbes. 


\section{Discussion}

Bio-organic fertilizer significantly reduced the $\mathrm{Fu}$ sarium wilt of watermelon. However, its mechanism was different. In the present study, the BOF inhibited soil pathogens and other possibly harmful microorganisms and stimulated some ecologically beneficial microbes. It also promoted the growth of indigenous microorganisms in Fusarium-infested soil. It changed the diversity of the microorganism communities, both in the watermelon rhizosphere and in infested bulk soil, and both for autochthonous microbes and allochthonous microbes. However, our earlier results (Wu et al., 2009, 2010) indicated that BOF increased the resistance of watermelon plants by promoting defense-related enzyme activities, thereby decreasing the Fusarium spp attack on the host. The obtained results were also consistent with those of previous work (Cao et al., 2011), showing that the final biocontrol effectiveness resulted from soil microbial ecological remediation but differed in terms of its biological mechanism.

The continuous cultivation of watermelon plants leads to an increase in pathogens and a resulting decrease in ecologically functioning microbes, especially beneficial bacteria, which leads to decreased soil functions and productivity. The results of this study showed that although the number of bacteria in Fusarium-infested soil decreased greatly, no significant difference in species richness was found between Fusarium-infested and healthy soils before the trial, whereas there was a significant difference in the index based on the proportion of species abundance (Shannon's index). This finding revealed that the continuous cultivation of watermelon caused a change in culturable microorganisms, leading to a disturbance in the inherent microbial equilibrium of the soil. However, little change in the microorganism species was observed. By adding species to the soil ecosystem, the species number in- creases the community-level stability, resulting in new interactions between the species and the environment, and a link between sub-communities through speciesspecies interactions that has no effect on the community-level stability (Ives et al., 2000). The organic fertilization systems increased the microbial biomass, shifted the structure and composition of the soil microbial community, and stimulated the microbial activity when compared with that of inorganic. Organic fertilization results in a more effective increase in soil organic matter content and microbial activity, and bioand chemical soil properties are improved relative to chemical fertilization. In many ways soil biochemical, micro- and biological properties are more suitable than physical and/or chemical properties for estimating alterations in soil quality and thereby tracking soil degradation . In this study, the application of fertilizer and BOF affected the dynamic balance of microbes that were established in a microcosm of watermelon soil. A significant difference was observed in the proportional abundance of species (Shannon's index) for the watermelon rhizosphere between all treatments and the control after BOF. However, there was no significant difference for other diversity indices (Margalef's, Simpson's and Berger-Parker's indices). This finding showed that the application of $\mathrm{CF}$, OF and BOF affected the quantities of culturable microorganisms in the rhizosphere and bulk soil, with $\mathrm{OF}$ and BOF especially facilitating microbial restoration to a normal level. Furthermore, significant differences were obtained for the species richness (Margalef's index), dominance measure (Simpson's index), and proportional abundance of species (Shannon's index). Our results were also confirmed by Cao et al. (2011), where the abundance of fungi and $\mathrm{G}^{+}$bacteria were increased by sheep manure and legume cover crop treatments. It has also been shown that treating soil with organic fertilizers results in higher concentrations of microbial biomass and DNA contents (Rehman et al., 
2016). In a study by 454 pyrosequencing revealed the presence of OTUs attributed to bacteria, yeasts and filamentous fungi in organically amended soils. Proteobacteria, Bacteroidetes and Firmicutes exhibited a significant dominance in the first 5 days, whereas Ascomycota became dominant 90 days after the organic amendment, with organic and inorganic fertilization producing similar grapevine yields.

It also implied that the application of OF and BOF can inhibit the harmful microbes, resulting in an increase in ecologically beneficial microbes and maintaining the normal ecological function of the soils. The soil functions were decentralized and assigned to small groups in the organic amendment soils. Long-term organic amendment supported stronger functional potentials and more interactions within the soil community relative to long-term chemical-only fertilization. This may be related to the soil stability and buffering capacity benefits derived from organic amendments, which explains the correlations intertaxa and between major groups and functional traits. This allows us to gain a more integrated understanding of microbiome and ecological rules guiding soil communities fostered by fertilization regimes (Ling et al., 2016). If biodiversity manipulations are less well controlled, then the biodiversity effects are weaker; and the effects of biodiversity variation on processes are weaker at the ecosystem level relative to the community level and negative at the population level (Balvanera et al., 2006). There have been many attempts to make use of biocontrol measures for the suppression of soil-borne plant pathogens. These attempts frequently involve the organisms into soil, which antagonizes the pathogens in vitro; these procedures try to disturb the microbiological equilibrium through the simple introduction of individual isolates into the environment. The antibiotics that are secreted by microorganisms may influence microbial diversity (Wardle, 2006). However, it is not surprising that the added microorganisms have often failed to become established, because biological cooperation and antagonisms within the ecosystem can control and regulate the composition of the microflora. Moreover, the climax population reflects the physical and chemical properties of the habitat. It is possible to alter the composition of the microflora by modifying the habitat, and subsequently, these microbial changes may destroy soil-borne plant pathogens (Mitchell and Alexander, 1961). Hydrolytic enzymes and antibiotics may play a key role in the antagonistic action of Trichoderma harzianum against fungal phytopathogens (Schirmböck et al., 1994).

In the present study, OF and BOF suppressed fungal growth and facilitated the recovery of ecologically beneficial bacteria in the rhizosphere and bulk soil. The results showed that there were natural, indigenous antagonistic microorganisms that maintained the inherent and natural balance of the ecosystem.

In our research, BOF synergized the relations among the ecologically beneficial, dominant populations of the rhizosphere and bulk soil. The CFU of the dominant pathogen populations in the watermelon rhizosphere decreased with the application of OF and BOF. Indigenous antagonistic microbes naturally co-exist and co-evolve with pathogens in soil. However, in most cases, they do not dominate because of unfavorable environmental conditions. The correction of these unfavorable conditions surely helps in the growth and action of these autochthonous antagonistic microorganisms. Fusarium spp. are antagonized by antifungal substance(s) and cannot infect bottle gourd and tomato plants growing in association with the inoculated plants because the roots of the different plants are in close contact with one another (Komada, 1975). Applying indigenous fungi during integrated control to reduce disease offers unusual opportunities for integration with other management systems because, simply, the fungi are always there (Singh et al., 1999). In the soil ecosystem, those dominant species act as controllers 
of ecosystem function, and they can provide temporary resistance to reductions in the ecosystem function when species loss is nonrandom. However, with the concurrent loss of beneficial interactions among rare and uncommon species, the most diverse community components may experience additional species loss and ecosystem dysfunction in the long term (Smith and Knapp, 2003).

In agricultural fields, diversified populations of aerobic endospore-forming bacteria, actinomycetes and fungi occur and may directly and indirectly improve crop productivity (Brian and Gardener, 2004). Many microorganisms, for example Bacillus and Paenibacillus spp., can stimulate plant health in different ways. By secreting antibiotic metabolites, certain microbial populations inhibit plant pathogens and pests, and others may directly promote crop host defenses before infection. In addition, many strains can aid in nutrient uptake by plants (Brian and Gardener, 2004). These strains share key roles in maintaining the soil ecological function, fertility and productivity. Soil microbial populations and their functions related to nutrient cycling contribute substantially to the regulation of soil fertility and the sustainability of agroecosystems.

\section{Conclusions}

Indigenous, antagonistic microorganisms are naturally present in watermelon soils. They contribute to a stable and well-functioning soil ecosystem that can support watermelon monoculture plantations. However, ecologically beneficial microbes can be severely inhibited by Fusarium oxysporum. Bio-organic fertilizer was shown to directly suppress Fusarium oxysporum f. sp. niveum and facilitate the growth of ecologically beneficial microbes, particularly by stimulating the growth and activities of indigenous, antagonistic microbes. This led to the reestablishment of equilibrium in the soil microbial ecosystem and recovery from pro- ductivity losses due to sick soils. The use of bio-organic fertilizers to recover normal soil functions that were lost during soil sickness should be further investigated.

\section{Acknowledgments}

We extend our thanks to the Natural Science Foundation of China (31670500), the Jiangsu Provincial Key project for Science and Technology (BE2017339), the Jiangsu Provincial Financial Support Program for Six-fields-talents-peaks (2009241) and the National Project for Chinese Sparkling Science and Technology (S2013C100403) from the Ministry of Science and Technology of China for their financial support. We are grateful to Dr. Kendall Joshua from Ohio State University for his kind help in improving our manuscript.

\section{References}

Ahemad, M., Kibret, M. 2014. Mechanisms and applications of plant growth promoting rhizobacteria: Current perspective. J. King Saud Univ. - Sci. 26: $1-20$.

Balvanera, P., Pfisterer, A.B., Buchmann, N., He, J.-S., Nakashizuka, T., Raffaelli, D., Schmid, B. 2006. Quantifying the evidence for biodiversity effects on ecosystem functioning and services. Ecol. Lett. 9: 1146-1156.

Booth, C. 1971. The genus Fusarium. UK. Farnham Royal, England: Commonwealth Agricultural Bureaux [for the] Commonwealth Mycological Institute.

Brian, B., Gardener, M. 2004. Ecology of Bacillus and Paenibacillus spp. in Agricultural Systems. Phytopathology. 94: 1252-1258.

Burrell, L.D., Zehetner, F., Rampazzo, N., Wimmer, B. Soja, G. 2016. Long-term effects of biochar on soil physical properties. Geoderma. 282: 96-102. 
Calleja-Cervantes, M.E., Fernández-González, A.J., Irigoyen, I., Fernández-López, M., Aparicio-Tejo P.M., Menéndez, S. 2015. Thirteen years of continued application of composted organic wastes in a vineyard modify soil quality characteristics. Soil Biol. Biochem. 90: 241-254.

Cao, Y., Zhang, Z., Ling, N., Yuan, Y., Zheng, X., Shen, B., Shen, Q. 2011. Bacillus subtilis SQR 9 can control Fusarium wilt in cucumber by colonizing plant roots. Biol. Fertil. Soils. 47: 495-506.

Chen, M., Xu, P., Zeng, G., Yang, C., Huang, D., Zhang, J. 2015. Bioremediation of soils contaminated with polycyclic aromatic hydrocarbons, petroleum, pesticides, chlorophenols and heavy metals by composting: Applications, microbes and future research needs. Biotechnol. Adv. 33: $745-755$.

Costa, J.L., Aparicio, V., Cerdà, A. 2015. Soil physical quality changes under different management systems after 10 years in the Argentine humid pampa. Solid Earth. 6: 361-371.

Debiase, G., Montemurro, F., Fiore, A., Rotolo, C., Farrag, K., Miccolis, A., Brunetti, G. 2016. Organic amendment and minimum tillage in winter wheat grown in Mediterranean conditions: Effects on yield performance, soil fertility and environmental impact. Eur. J. Agron. 75: 149-157.

Dignam, B.E.A., O'Callaghan, M., Condron, L.M., Raaijmakers, J.M., Kowalchuk, G.A., Wakelin, S.A. 2016. Challenges and opportunities in harnessing soil disease suppressiveness for sustainable pasture production. Soil Biol. Biochem. 95: $100-111$.

Fulton, H.R. 1927. Organic fertilizers and cotton wilt control. Science 66: 193-194.

Girlanda, M., Perotto, S., Moenne-Loccoz, Y., Bergero, R., Lazzari, A., Defago, G., Bonfante, P., Luppi, A.M. 2001. Impact of biocontrol Pseudomonas fluorescens $\mathrm{CHA} 0$ and a genetically modi- fied derivative on the diversity of culturable fungi in the cucumber rhizosphere. Appl. Environ. Microbiol. 67: 1851-1864.

Gordon, R.E., Haynes, W.C., Pang, C.H.-N. 1973. The genus Bacillus. Agricultural Research Service, U.S. Dept. of Agriculture, Washington, D.C.

Hasegawa, T., Takizawa, M., Tanida, S. 1983. A Rapid Analysis for Chemical Grouping of Aerobic Actinomycetes. J. Gen. Appl. Microbiol. 29: 319-322.

Ives, A.R., Klug, J.L., Gross, K. 2000. Stability and species richness in complex communities. Ecol. Lett. 3: 399-411.

Jimtha, J.C., Jishma, P., Arathy, G.B., Anisha, C., Radhakrishnan, E.K. 2016. Identification of plant growth promoting Rhizosphere Bacillus sp. WG4 antagonistic to Pythium myriotylum and its enhanced antifungal effect in association with Trichoderma. J. Soil Sci. Plant Nutr. 16: 578-590

Komada, H. 1975. Development of a selective medium for quantitative isolation of Fusarium oxysporum from natural soil. Rev. Plant Prot. Res. 8: 114-124.

Ling, N., Zhu, C., Xue, C., Chen, H., Duan, Y., Peng, C., Guo, S., Shen, Q. 2016. Insight into how organic amendments can shape the soil microbiome in long-term field experiments as revealed by network analysis. Soil Biol. Biochem. 99: 137-149.

Marín-Benito, J.M., Herrero-Hernández, E., Andrades, M.S., Sánchez-Martín, M.J., RodríguezCruz, M.S. 2014. Effect of different organic amendments on the dissipation of linuron, diazinon and myclobutanil in an agricultural soil incubated for different time periods. Sci. Total Environ. 476-477: 611-621.

Mitchell, R., Alexander, M. 1961. The Mycolytic Phenomenon and Biological Control of Fusarium in Soil. Nature. 190: 109-110.

Natsch, A., Keel, C., Hebecker, N., Laasik, E., Défago, G. 1997. Influence of biocontrol strain Pseu- 
domonas fluorescens $\mathrm{CHA} 0$ and its antibiotic overproducing derivative on the diversity of resident root colonizing pseudomonads. FEMS Microbiol. Ecol. 23: 341-352.

Rehman, K., Ying, Z., Andleeb, S., Jiang, Z., Olajide, E.K. 2016. Short term influence of organic and inorganic fertilizer on soil microbial biomass and DNA in summer and spring. J. Northeast Agric. Univ. Engl. Ed. 23: 20-27.

Schirmböck, M., Lorito, M., Wang, Y.L, Hayes, C.K., Arisan-Atac, I., Scala, F., Harman, G.E, Kubicek, C.P. 1994. Parallel formation and synergism of hydrolytic enzymes and peptaibol antibiotics, molecular mechanisms involved in the antagonistic action of Trichoderma harzianum against phytopathogenic fungi. Appl. Environ. Microbiol. 60: 4364-4370.

Shirling, E.B., Gottlieb, D. 1966. Methods for characterization of Streptomyces species 1. Int. J. Syst. Evol. Microbiol. 16: 313-340.

Singh, B.K., Arora, S., Kuhad, R.C., Mukerji, K.G. 1999. Use of Fungi in the Control of Plant Pathogens. p. 153-162. In Singh, J., Aneja, K.R. (eds.), From Ethnomycology to Fungal Biotechnology. Springer US, Boston, MA.

Sirohi, G., Upadhyay, A., Srivastava, P.S., Srivastava, S. 2015. PGPR mediated Zinc biofertilization of soil and its impact on growth and productivity of wheat. J. Soil Sci. Plant Nutr. 15: 202-216

Smith, M.D., Knapp, A.K. 2003. Dominant species maintain ecosystem function with non-random species loss. Ecol. Lett. 6: 509-517.
Speller, D.C.E. 1978. The Shorter Bergey's Manual of Determinative Bacteriology. J. Clin. Pathol. 31: 296-297.

Wardle, D.A. 2006. The influence of biotic interactions on soil biodiversity. Ecol. Lett. 9: 870-886.

Webley, D.M. 1973. Fungi in Agricultural Soils By Domsch K.H. and Gams,W. (Translated from the German by Hudson P.S.) London: Longmans Green (1972), pp. 290. Exp. Agric. 9: 383-383.

Wu, H., Luo, J., Raza, W., Liu, Y., Gu, M., Chen, G., Hu, X., Wang, J., Mao, Z., Shen, Q. 2010. Effect of exogenously added ferulic acid on in vitro Fusarium oxysporum $f$. sp. niveum. Sci. Hortic. 124: 448-453.

Wu, H., Yang, X., Fan, J., Miao, W., Ling, N., Xu, Y., Huang, Q., Shen, Q. 2009. Suppression of Fusarium wilt of watermelon by a bio-organic fertilizer containing combinations of antagonistic microorganisms. BioControl. 54: 287.

Wu, Y., Zhao, C., Farmer, J., Sun, J. 2015. Effects of bio-organic fertilizer on pepper growth and $\mathrm{Fu}-$ sarium wilt biocontrol. Sci. Hortic. 193: 114-120.

Yazdanpanah, N., Mahmoodabadi, M., Cerdà, A. 2016. The impact of organic amendments on soil hydrology, structure and microbial respiration in semiarid lands. Geoderma. 266: 58-65. 